\title{
Identifikasi Faktor Penghambat Seseorang Menggunakan Gigi Tiruan
}

\author{
${ }^{1}$ Jessica L. Situni, ${ }^{2}$ Vonny NS. Wowor, ${ }^{2}$ Juliatri \\ ${ }^{1}$ Mahasiswa Program Studi Kedokteran Gigi Fakultas Kedokteran Universitas Sam Ratulangi Manado \\ ${ }^{2}$ Dosen di Program Studi Kedokteran Gigi Fakultas Kedokteran Universitas Sam Ratulangi
}

\begin{abstract}
ABSTRAK
Karies gigi dan penyakit periodontal merupakan penyebab utama kehilangan gigi. Sumber dari kedua penyakit tersebut akibat terabaikannya kebersihan gigi dan mulut sehingga terjadi akumulasi plak. Kehilangan gigi yang tidak diganti dengan gigi tiruan dapat berdampak pada fisik maupun psikis seseorang, namun pada umumnya masyarakat tidak mengganti gigi yang hilang dengan gigi tiruan. Tujuan penelitian ini untuk mengidentifikasi faktor penghambat seseorang menggunakan gigi tiruan.

Penelitian ini merupakan penelitian deskriptif yang dilakukan di kelurahan Maasing kecamatan Tuminting. Besar sampel 108 orang, ditentukan dengan menggunakan rumus Slovin. Teknik pengambilan sampel menggunakan metode purposif. Hasil penelitian menunjukkan faktor ekonomi memiliki persentase tertinggi sebagai faktor penghambat seseorang menggunakan gigi tiruan, yaitu sebanyak 76 responden $(70,37 \%)$, faktor pengetahuan sebanyak 48 responden $(44,44 \%)$, faktor waktu sebanyak 33 responden (30,56\%), faktor jarak sebanyak 21 responden $(19,44 \%)$, faktor pengalaman sebanyak 20 responden $(18,52 \%)$, faktor sumber daya manusia sebanyak 19 responden $(17,59 \%)$, faktor sarana pelayanan kesehatan sebanyak 16 responden $(14,81 \%)$ dan yang terendah yaitu alasan lainnya sebanyak 4 responden $(3,7 \%)$. Faktor ekonomi, pengetahuan dan waktu merupakan 3 faktor terbesar yang paling menghambat masyarakat sehingga tidak menggunakan gigi tiruan.
\end{abstract}

Kata kunci : faktor penghambat, kehilangan gigi, penggunaan gigi tiruan

\begin{abstract}
Dental caries and periodontal disease are some of the main causes of tooth loss. These two conditions are caused by a built-up of plak due to poor dental hygiene practice. Tooth loss may affect someone physically and mentally if the loss tooth is not replaced by denture. However it is uncommon for people to replace their loss tooth with denture. The purpose of this research is to find out which factor reduce the chance of someone from getting denture.

This research is a descriptive study conducted at Maasing in Tuminting. The samples are 108 respondents, by using the Slovin formula. The technique using purposive sampling method. Below are the factors which are listed in the survey: Economic 76 respondent (70.37\%), Education 48 respondent (44.44\%), Time 33 respondent (30.56\%), Distance 21 respondent (19.44\%), Experience 20 respondent (18.52\%), Human Resource 19 respondent (17.59\%), Quality of Healthcare 16 respondent (14.81\%), Others 4 respondent (3.7\%). Economic, knowledge and time factors are the 3 largest so that people do not use denture.
\end{abstract}

Keywords: inhibiting factors, tooth loss, use of dentures

Koresponden: Jessica L. Situni, Program Studi Kedokteran Gigi Fakultas Kedokteran Universitas Sam Ratulangi. E-mail: jessicasituni@gmailcom

\section{PENDAHULUAN}

Gigi merupakan salah satu organ tubuh manusia yang penting. Individu yang kehilangan gigi akan mengalami kesulitan dalam mengunyah makanan. Gigi berfungsi dalam pengunyahan sebagai proses awal pencernaan makanan, di samping itu juga gigi berpengaruh dalam fungsi bicara. Seseorang yang telah mengalami kehilangan gigi, khususnya gigi depan akan sulit mengucapkan huruf-huruf tertentu, misalnya huruf f, v, th, ph. Gigi juga berpengaruh terhadap estetik seseorang. Banyak profesi yang membutuhkan estetika, misalnya profesi yang harus berinteraksi dengan orang banyak, misalnya seorang model, guru, penyanyi, artis, sales perusahaan. ${ }^{1,2}$ 
Kehilangan gigi dapat dialami siapa saja, terlebih bagi mereka yang kurang memerhatikan kebersihan gigi dan mulutnya. Kurangnya perhatian akan kebersihan gigi dan mulut dapat menyebabkan terjadinya karies, penyakit periodontal yang merupakan penyebab utama kehilangan gigi. Kehilangan gigi juga dapat terjadi akibat trauma atau karena alasan tertentu, misalnya untuk keperluan perawatan Ortodonti. ${ }^{3,4}$

Gigi yang hilang dan tidak segera diganti dapat berdampak pada kesehatan gigi dan mulut, antara lain terjadinya migrasi dan rotasi, erupsi berlebih, penurunan efisiensi kunyah, gangguan pada sendi temporo-mandibula, beban berlebihan pada jaringan pendukung, kelainan bicara, memburuknya penampilan, terganggunya kebersihan mulut, atrisi dan dapat berefek terhadap jaringan lunak mulut. ${ }^{2}$

Data survei Litbangkes tahun 2010 menunjukkan bahwa masyarakat di Indonesia yang mendapat pelayanan pencabutan gigi sebesar $79,6 \%$ dan yang menggunakan gigi tiruan hanya sebesar 4,5\%, hal ini menggambarkan bahwa banyak kasus kehilangan gigi yang tidak ditangani. Hal ini mungkin disebabkan oleh rendahnya pengetahuan serta kesadaran masyarakat. Sebagian masyarakat mungkin saja menganggap kehilangan gigi dan tidak diganti dengan gigi tiruan tidak akan menimbulkan masalah lain dalam rongga mulut. ${ }^{5}$

Kehilangan gigi merupakan hal umum yang terjadi pada masyarakat saat ini. Beberapa faktor penghambat dalam penggunaan gigi tiruan antara lain faktor ekonomi dan pengetahuan. Dalam pembuatan gigi tiruan dibutuhkan biaya yang tidak sedikit. Jika tingkat ekonomi masyarakat tersebut rendah, maka dapat menghambat untuk penggunaan gigi tiruan. Di samping itu, pengetahuan masyarakat yang rendah juga sebagai penghambat dalam penggunaan gigi tiruan.

Observasi awal yang dilakukan di kelurahan Maasing kecamatan Tuminting kota Manado menunjukkan banyak masyarakat yang mengalami kehilangan gigi namun tidak diganti dengan gigi tiruan. Data tentang kondisi ini hingga kini belum tersedia, baik di tingkat kelurahan, kota maupun provinsi. Hal ini yang membuat penulis tertarik untuk melakukan penelitian mengenai faktor-faktor apa saja yang menghambat masyarakat tersebut tidak menggunakan gigi tiruan. Alasan lainnya karena masyarakat kelurahan Maasing merupakan masyarakat pesisir dengan ciri kebaharian yang menjadi ciri khas Universitas Sam Ratulangi.

\section{BAHAN DAN METODE}

Penelitian yang dilakukan merupakan jenis penelitian deskriptif dan dilaksanakan di Kelurahan Maasing Kecamatan Tuminting Kota Manado. Sampel dalam penelitian ini yaitu masyarakat yang telah kehilangan gigi dan tidak menggunakan gigi tiruan. Besar sampel diperoleh dengan menggunakan rumus Slovin, yaitu sebanyak 108 orang. Pengambilan sampel dilakukan dengan teknik purposive sampling, dimana sampel diambil berdasarkan pertimbangan peneliti yaitu sesuai kriteria inklusi dan eksklusi yang telah ditetapkan.

Kriteria inklusi yaitu berusia 17 tahun ke atas, bersedia secara sukarela sebagai subjek penelitian, hadir pada saat pengambilan data, bersifat kooperatif selama pengambilan data. Sedangkan kriteria eksklusi yaitu berusia 17 tahun ke atas dan sedang menggunakan gigi tiruan, tidak ada kehilangan gigi. Penelitian ini diawali dengan adanya surat pengantar permohonan ijin penelitian yang diperoleh dari Program Studi Kedokteran Gigi. Penelitian dimulai setelah dikeluarkannya ijin dari pihak kelurahan Maasing kecamatan Tuminting. Responden yang terpilih sebagai subjek penelitian, dimintakan persetujuan terlebih dahulu dan persetujuan dibuktikan dengan adanya penandatangan surat persetujuan (informed consent), barulah penelitian dilakukan dengan mengedarkan kuesioner untuk dijawab. Penelitian ini dilakukan dengan menggunakan data primer dan data sekunder. Data primer diperoleh secara langsung dari responden melalui wawancara dan kuesioner pada masyarakat kelurahan Maasing kecamatan Tuminting kota Manado yang langsung ditemui di rumah-rumah masyarakat. Data sekunder diperoleh dari profil kelurahan berupa identitas kelurahan dan jumlah masyarakat. Data dikumpulkan dan pengolahan data dilakukan secara manual kemudian dianalisa berdasarkan persentase dan disajikan dalam bentuk tabel dan diagram.

\section{HASIL PENELITIAN}

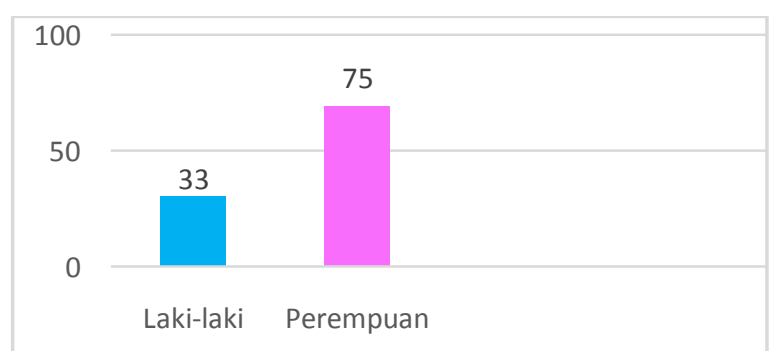

Gambar 7. Distribusi responden berdasarkan jenis kelamin.

Diagram pada gambar 7 di atas menunjukkan dari 108 responden terdapat 33 responden 
$(30,56 \%)$ berjenis kelamin laki-laki dan 75 responden $(69,44 \%)$ berjenis kelamin perempuan.

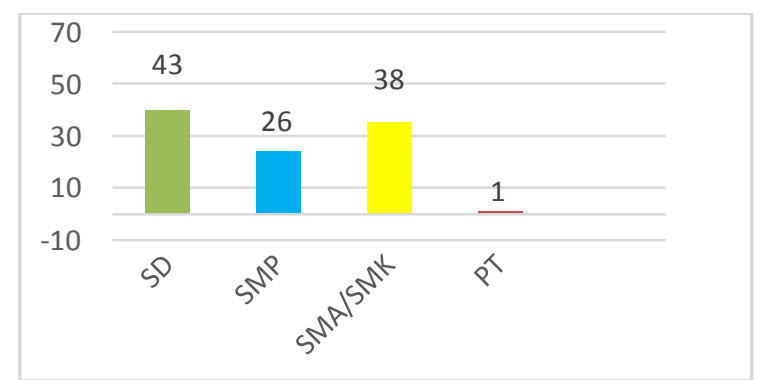

Gambar 8. Diagram distribusi responden berdasarkan tingkat pendidikan.

Gambar 8 menunjukkan bahwa dari 108 responden di kelurahan Maasing kecamatan Tuminting diketahui jumlah responden dengan tingkat pendidikan SD merupakan responden terbanyak dengan jumlah 43 responden $(39,81 \%)$, paling sedikit yaitu perguruan tinggi sebanyak 1 responden $(0,93 \%)$.

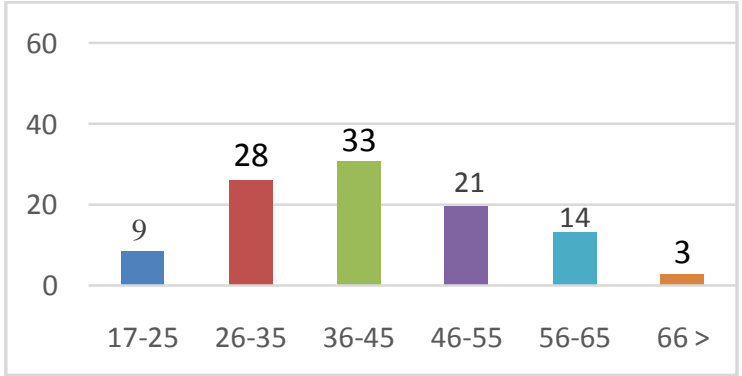

Gambar 9. Diagram distribusi responden berdasarkan rentang usia menurut Depkes RI.

Gambar 9 menunjukkan bahwa dari 108 responden yang diteliti, responden terbanyak pada rentang usia 36-45 tahun dengan jumlah 33 responden $(30,56 \%)$, usia 26-35 tahun sebanyak 28 responden $(25,93 \%)$, usia $46-55$ tahun sebanyak 21 responden $(19,44 \%)$, usia 56-65 tahun sebanyak 14 responden $(12,96 \%)$, usia 17 25 tahun sebanyak 9 responden $(8,33 \%)$ dan yang paling sedikit yaitu usia 66 tahun keatas berjumlah 3 responden $(2,78 \%)$.

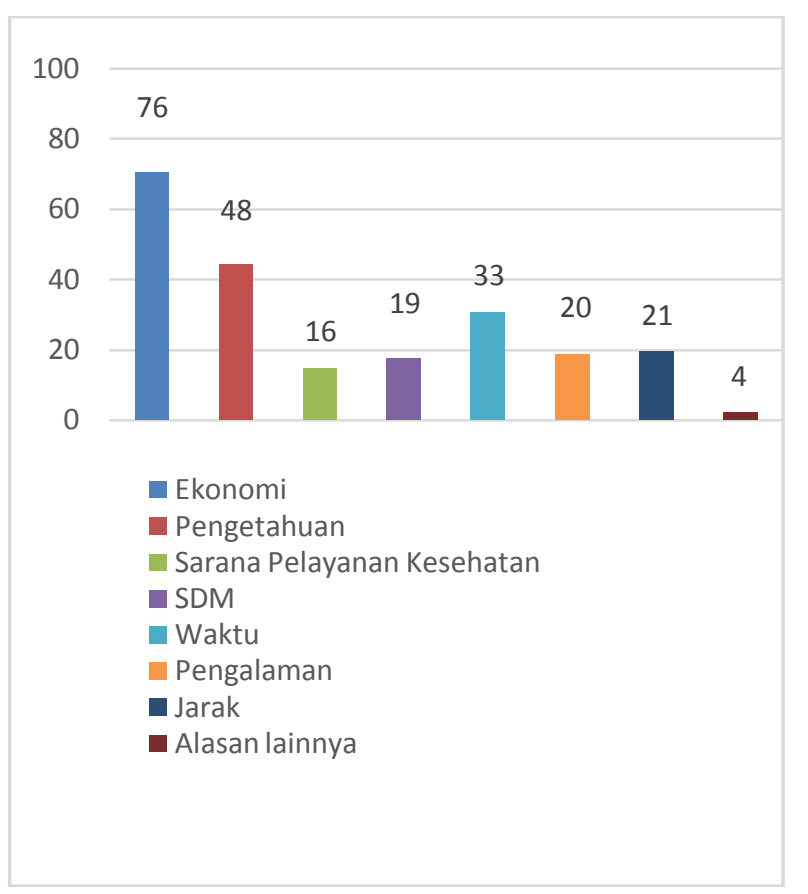

Gambar 10. Diagram distribusi berdasarkan faktor penghambat penggunaan gigi tiruan.

Distribusi responden berdasarkan faktor penghambat penggunaan gigi tiruan di atas menunjukkan bahwa faktor ekonomi memiliki persentase tertinggi yaitu sebanyak 76 responden $(70,37 \%)$, faktor pengetahuan sebanyak 48 responden $(44,44 \%)$, faktor waktu sebanyak 33 responden $(30,56 \%)$, faktor jarak sebanyak 21 responden $(19,44 \%)$, faktor sumber daya manusia sebanyak 19 responden $(17,59 \%)$, faktor pengalaman sebanyak 20 responden $(18,52 \%)$, faktor sarana pelayanan kesehatan sebanyak 16 responden $(14,81 \%)$ dan yang terendah yaitu alasan lainnya sebanyak 4 responden $(3,7 \%)$.

\section{PEMBAHASAN}

Dari hasil penelitian tentang faktor penghambat sehingga responden tidak menggunakan gigi tiruan, didapatkan hasil bahwa faktor yang paling menghambat masyarakat kelurahan Maasing kecamatan Tuminting dalam penggunaan gigi tiruan ialah faktor ekonomi. Sebanyak 76 responden $(70,37 \%)$ dari 108 responden yang diteliti menyatakan bahwa pembuatan gigi tiruan membutuhkan biaya yang tidak sedikit. Peneliti berasumsi hal ini wajar saja karena dalam pembuatan gigi tiruan dibutuhkan peralatan, bahan, keterampilan dan teknologi yang khusus. Tahapan pembuatan gigi tiruan tidak hanya dilakukan di klinik saja tetapi ada tahapan yang harus dikerjakan di laboratorium, yang antara lain merupakan faktor penyebab meningkatnya biaya pembuatan gigi tiruan. Di samping itu daerah Sulawesi Utara belum tersedia 
laboratorium yang khusus untuk pembuatan gigi tiruan sehingga dokter gigi harus mengirim pekerjaan tersebut ke laboratorium yang berada di luar kota. Hal ini mungkin juga menjadi salah satu faktor yang menyebabkan makin meningkatnya biaya pembuatan gigi tiruan. Alasan ini didukung dengan pernyataan Sulastomo yang menyatakan bahwa beberapa tahun terakhir ini masalah biaya kesehatan (rumah sakit, dokter, obat dan lainlainnya) telah banyak menarik perhatian, tidak saja di kalangan dunia kedokteran, tetapi juga di luar kalangan kedokteran dan terjadi tidak saja di dalam negeri, tetapi juga di luar negeri. Meningkatnya biaya pelayanan terjadi seiring dengan berkembangnya teknologi. ${ }^{23}$ Ini juga didukung dengan penelitian yang dilakukan oleh Teofilo yang menyatakan bahwa $88 \%$ dari subjek yang diteliti memiliki kendala keuangan dalam pembuatan gigi tiruan. ${ }^{24}$

Faktor pengetahuan merupakan faktor kedua tertinggi yang dianggap responden merupakan penghambat sehingga responden tidak menggunakan gigi tiruan, yaitu sebanyak 48 responden $(44,44 \%)$ dari 108 responden. Menurut pendapat penulis, hal ini dikarenakan subjek yang diteliti masih kurang memahami dampak dari kehilangan gigi. Kehilangan gigi yang tidak diganti bisa berdampak pada fisik maupun psikis seseorang. Contoh dampak fisik berupa terjadinya pergeseran gigi tetangga untuk mengisi daerah yang kosong, sehingga dapat memengaruhi fungsi pengunyahan ataupun kesehatan gigi secara keseluruhan. Susunan gigi yang tidak teratur akibat terjadinya migrasi, rotasi ataupun ekstrusi dapat menyebabkan gangguan pada fungsi pengunyahan akibat susunan gigi geligi yang tidak teratur. Hal ini seperti pada penelitian yang dilakukan oleh Hutton dkk yang menyatakan bahwa makanan yang dikonsumsi sebelum masuk lebih dalam menuju alat pencernaan harus melewati rongga mulut. Di rongga mulut ini makanan sudah mulai menjalani proses pencernaan. Kelancaran pengunyahan makanan di dalam rongga mulut bergantung pada kelengkapan dan keteraturan susunan gigi. Jumlah gigi geligi yang tidak lengkap serta susunannya yang tidak teratur akan menurunkan keefektifan fungsi pengunyahan. ${ }^{13}$

Davis dkk menyatakan bahwa kehilangan gigi juga memengaruhi kondisi psikis dari seseorang dalam kehidupan sehari-hari. Banyak orang kesulitan menerima keadaan akibat kehilangan gigi. Mereka merasa kurang percaya diri, merasa terhambat dalam melaksanakan pekerjaan seharihari, dan kurang mampu menerima perubahan bentuk wajah yang terjadi akibat kehilangan gigi. ${ }^{12}$ Terlebih bagi mereka yang mengalami kehilangan gigi bagian depan karena dapat memberikan kesan lebih tua dari usia sebenarnya.

Dilihat dari tingkat pendidikan masyarakat setempat, dengan rata-rata pendidikan terakhir yaitu SD hingga SMA/SMK dan yang memiliki jumlah paling banyak yaitu SD sebanyak 43 responden $(39,81 \%)$. Peneliti berpendapat bahwa semakin tinggi pendidikan seseorang, semakin banyak pengetahuan yang dimiliki sebaliknya semakin rendah tingkat pendidikan sesorang semakin sedikit pula pengetahuan yang dimiliki. Hal ini tergambar pada hasil penelitian yang ada, dimana rendahnya tingkat pendidikan menggambarkan rendahnya pengetahuan yang dimiliki responden. Pernyataan ini ditunjang dengan hasil penelitian oleh Temitope dkk, yang menerangkan bahwa populasi dengan tingkat pendidikan yang lebih tinggi lebih banyak memiliki informasi tentang kebutuhan kesehatan dan dapat mencari perawatan gigi lebih awal dan lebih sering dari pada orang-orang dari status pendidikan rendah yang hanya dapat mencari pengobatan gigi ketika ada morbiditas. ${ }^{25}$

Hasil penelitian selanjutnya memperlihatkan sebanyak 20 responden $(18,52 \%)$ dari 108 responden memilih pengalaman sebagai faktor penghambat dalam penggunaan gigi tiruan. Pengalaman didapat baik melalui kesan secara pribadi dalam menggunakan gigi tiruan atau berasal dari pengalaman orang lain yang pernah menggunakan gigi tiruan. Apabila penggunaan gigi tiruan sebelumnya memiliki kesan yang nyaman dan baik, maka hal yang sama diharapkan pada gigi tiruan yang baru. Namun bila gigi tiruan yang lama tidak memuaskan dan memiliki kesan yang buruk misalnya ketidak nyamanan dalam penggunaan gigi tiruan, maka hal ini dapat menyebabkan masyarakat tidak ingin menggunakan gigi tiruan lagi. Apabila sebelumnya belum ada pengalaman mengenai penggunaan gigi tiruan, maka pengalaman tersebut mungkin diperoleh lewat pengalaman teman-teman atau kenalan yang pernah menggunakan gigi tiruan. Kesan yang ditimbulkan dapat bersifat positif atau pun negatif. Apabila kesan positif yang disampaikan maka dapat mendorong responden untuk menggunakan gigi tiruan, tetapi jika kesan negatif yang disampaikan maka hal ini dapat merupakan penghambat bagi responden untuk menggunakan gigi tiruan.

Pada penelitian ini mungkin saja pengalaman yang diperoleh memberikan kesan negatif, misalnya pengalaman pribadi dalam pemakaian gigi tiruan. Pengalaman buruk dalam pemakaian gigi tiruan mengakibatkan kecil kemungkinan bagi seseorang untuk mau menggunakan gigi 
tiruan kembali. Demikian halnya bila seseorang mendapatkan pengalaman tersebut dari lingkungan keluarga atau teman dan akan membentuk persepsinya terhadap penggunaan gigi tiruan.

Menurut Notoatmodjo pengalaman atau pengetahuan yang dimiliki seseorang merupakan faktor yang sangat berperan dalam menginterpretasikan stimulus yang diperoleh. Pengalaman masa lalu atau apa yang telah dipelajari akan menyebabkan terjadinya perbedaan interpretasi. Apa yang dilihat akan memengaruhi apa yang akan dirasakan di kemudian hari. ${ }^{26}$ Selain itu juga pengalaman yang didasari oleh pengetahuan akan lebih langgeng dari pada perilaku yang tidak didasari oleh pengetahuan.

Faktor penghambat lainnya yaitu waktu. Sebanyak 33 responden $(30,55 \%)$ dari 108 responden yang diteliti menyatakan tidak memiliki waktu untuk melakukan pembuatan gigi tiruan dikarenakan sibuk dengan pekerjaan. Peneliti berasumsi bahwa masyarakat menganggap pekerjaan lebih penting daripada kesehatan gigi dan mulut. Apabila mereka tidak bekerja, maka penghasilan yang didapatkan akan berkurang padahal harus membiayai keluarga mereka. Gunadi dkk, menyatakan bahwa perawatan gigi tiruan membutuhkan waktu yang tidak sedikit. ${ }^{2}$ Tidak hanya dengan satu kali kunjungan saja ke dokter gigi melainkan harus beberapa kali kunjungan. Hal ini wajar karena dalam pembuatan gigi tiruan dibutuhkan penanganan yang bertahap sehingga tidak bisa diselesaikan dalam satu kali kunjungan saja. Selain sibuk dengan pekerjaan mereka, jarak antara tempat tinggal dengan sarana pelayanan kesehatan ada dalam hal ini Puskesmas dan rumah sakit cukup jauh sehingga membutuhkan pula biaya transportasi dan waktu yang lebih banyak. Hal ini dapat dilihat dari hasil penelitian bahwa sebanyak 21 responden $(19,44 \%)$ dari 108 responden memilih faktor jarak sebagai faktor penghambat untuk menjangkau sarana pelayanan kesehatan yang ada dan sebanyak 16 responden $(14,81 \%)$ dari 108 responden memilih tidak adanya sarana pelayanan kesehatan di tempat tinggal mereka.

Selain sarana pelayanan kesehatan yang memadai, ketersediaan tenaga kerja yang kompeten dalam hal ini dokter gigi juga sangat memengaruhi masyarakat untuk mendapatkan pelayanan kesehatan yang sesuai dengan kebutuhan yang diperlukan. Hasil penelitian yang telah dilakukan di kelurahan Maasing kecamatan Tuminting didapatkan sebanyak 19 responden $(17,59 \%)$ dari 108 responden memilih ketersediaan sumber daya manusia sebagai penghambat penggunaan gigi tiruan. Dalam peraturan menteri kesehatan nomor 512/Menkes/Per/IV/2007 tentang izin praktek dan pelaksanaan praktek kedokteran pada bab 1 pasal 1 poin 7 menyebutkan pelayanan medis adalah pelayanan kesehatan yang diberikan oleh dokter dan dokter gigi sesuai dengan kompetensi dan kewenangannya yang dapat berupa pelayanan promotif, preventif, diagnostik, konsultatif, kuratif, atau rehabilitatif.

Pelayanan dokter gigi tidak hanya mengobati tetapi juga melayani pembuatan gigi tiruan. Namun menurut keterangan yang didapatkan melalui wawancara kepada masyarakat bahwa dokter gigi puskesmas belum melayani pembuatan gigi tiruan. Dokter gigi puskesmas hanya mengobati sakit gigi, melayani pencabutan, dan penambalan gigi, sehingga untuk pembuatan gigi tiruan, masyarakat harus pergi ke tempat praktek swasta dokter gigi. Biaya yang dibutuhkan untuk ke tempat praktek swasta dokter gigi jauh lebih mahal dibandingkan dengan ke Puskesmas, karena pelayanan di Puskesmas bisa menggunakan JAMKESMAS yang dapat meringankan biaya pengobatan yang dibiayai oleh pemerintah sedangkan di tempat praktek dokter gigi tidak bisa menggunakan JAMKESMAS.

Sebanyak 4 responden $(3,7 \%)$ dari 108 responden memilih faktor alasan lainnya yang dikelompokkan ke dalam faktor estetika sebagai penghambat dalam penggunaan gigi tiruan. Responden merasa tidak perlu menggunakan gigi tiruan karena hanya gigi belakang yang hilang dan tidak mengganggu estetika. Adapun alasan lainnya berupa responden menganggap gigi tiruan sudah tidak dibutuhkan lagi dikarenakan usia yang sudah lanjut, sehingga estetika tidak menjadi prioritas lagi. Hal-hal inilah yang merupakan faktor penghambat masyarakat kelurahan Maasing kecamatan Tuminting untuk menggunakan gigi tiruan.

\section{SIMPULAN}

1. Faktor-faktor yang teridentifikasi menghambat masyarakat kelurahan Maasing kecamatan Tuminting sehingga tidak menggunakan gigi tiruan adalah faktor ekonomi, faktor pengetahuan, faktor waktu, faktor jarak, faktor sumber daya manusia, faktor pengalaman, faktor sarana pelayanan kesehatan, dan faktor alasan lainnya yang dikelompokkan dalam faktor estetika.

2. 3 faktor terbesar yang paling menghambat masyarakat kelurahan Maasing kecamatan Tuminting sehingga tidak menggunakan gigi 
tiruan adalah faktor ekonomi, faktor pengetahuan, dan faktor waktu.

\section{SARAN}

1. Diharapkan pemerintah dapat mengupayakan peningkatan derajat ekonomi masyarakat, misalnya dengan membuka lapangan kerja untuk masyarakat atau dengan meningkatkan status pendidikan sehingga diharapkan dapat terjadi perbaikan status ekonomi masyarakat.

2. Diharapkan pemerintah melalui instansi terkait dalam bidang kesehatan dapat memasukkan pengetahuan tentang dampak kehilangan gigi bagi kesehatan gigi dan mulut dalam program-program preventif maupun promotif dalam rangka meningkatkan derajat kesehatan masyarakat khususnya mengenai kesehatan gigi dan mulut.

3. Diharapkan pemerintah dapat meningkatkan pelayanan dalam bidang kesehatan gigi dan mulut dengan menyiapkan fasilitas pelayanan perawatan gigi tiruan di Puskesmas sehingga masyarakat dapat memperoleh pelayanan perawatan gigi tiruan yang terjangkau namun bermutu.

4. Diharapkan masyarakat dapat lebih menyadari akan dampak dari kehilangan gigi yang tidak diganti dengan gigi tiruan.

\section{DAFTAR PUSTAKA}

1. Maulani C, Enterprise J. Kiat merawat gigi anak. Jakarta: PT. Elex Media Komputindo; 2005. h. 6.

2. Gunadi HA, Margo M, Burhan LK, Suryatenggara F, Setabudi I. Buku ajar ilmu geligi tiruan sebagian lepasan. Ed. ${ }^{\mathrm{ke}-1}$. Jakarta: Hipoktrates; 1991. h. 30-9.

3. Wahyukundari MA. Perbedaan kadar matrix metalloproteinase-8 setelah scaling dan pemberian tetrasiklin pada penderita periodontitis kronis. Jurnal PDGI. 58(1) : 16. [Cited 23 April 2013]. Available from URL :http://www.pdgi.or.id/jurnal/detail/perbedaan -kadar-matrix-metalloproteinase-8-setelahscaling-dan-pemberian-tetrasiklin-padapenderita-periodontitis-kronis

4. Kida IA, Åstrøm AN, Strand GV, Masalu JR. Clinical and socio-behavioral correlates of tooth loss: a study of older adults in Tanzania; 2006. [Cited 23 April 2013]. Available from URL : http://www.biomedcentral.com/14726831/6/5.

5. Agtini MD. Persentase pengguna protesa di Indonesia tahun 2010. [serial online] 2010. [Cited 24 April 2013]. Available from : URL; http://ejournal.litbang.depkes.go.id/index.php/ MPK/article/view/782
6. Sulastomo. Manajemen kesehatan. Gramedia Pustaka Utama. Jakarta 2003.

7. Teofilo L T, Leles C R. Patient's selfperceived impacts and prosthodontic needs at the time and after tooth loss. Braz Dent Journal. 2007; 18(2):91-96.

8. Hutton B, Feine J, Morais J. Is there an association between edentulism and nutritional state?. J can dent assoc [serial online] 2002; [Cited 23 April 2013]; 68 (3): [183-7]. Avalaible from : URL: www.webdentistry.com/Download-index-reqgetit-lid-62.html

9. Davis DM, Fiske J, Scott B, Radford DR. The emotional effect of tooth loss: a preliminary study. Br. Dent J 2000; 188 (9): 503-6.

10. Esan T A, Olusile AO, Akeredolu PA and Esan AO. Socio-demographic factors and edentulism the Nigerian experience.J BMC Oal Health; 2004. 4(3):1-6.

11. Notoatmodjo S. Promosi kesehatan. Rineka cipta. Jakarta. 2010.

Gambar 8. Diagram distribusi responden berdasarkan tingkat pendidikan.

Gambar 8 menunjukkan bahwa dari 108 responden di kelurahan Maasing kecamatanting diketahui jumlah responden dengan tingkat pendidikan SD merupakan responden terbanyak de 
